Article

\title{
Morphology and Structural Stability of Bismuth-Gadolinium Co-Doped Ceria Electrolyte Nanopowders
}

\author{
Grazia Accardo ${ }^{1}\left(\right.$, Luca Spiridigliozzi ${ }^{2} \oplus$, Gianfranco Dell'Agli ${ }^{2, *}$, , Sung Pil Yoon ${ }^{1}$ and \\ Domenico Frattini ${ }^{3}$ (1) \\ 1 Center of Hydrogen-Fuel Cell Research, Korea Institute of Science and Technology, Hwarangno 14-gil, \\ Seongbuk-gu, Seoul 136-791, Korea; d16605@kist.re.kr (G.A.); spyoon@kist.re.kr (S.P.Y.) \\ 2 Department of Civil and Mechanical Engineering, University of Cassino and Southern Lazio, \\ Via G. Di Biasio 43, 03043 Cassino (FR) Italy; 1.spiridigliozzi@unicas.it \\ 3 Graduate School of Energy and Environment, Seoul National University of Science and Technology, \\ 232 Gongneung-ro, Nowon-gu, Seoul 01811, Korea; domenico.frattini@seoultech.ac.kr \\ * Correspondence: dellagli@unicas.it; Tel.: +39-776-2993682
}

Received: 28 August 2019; Accepted: 26 September 2019; Published: 28 September 2019

\begin{abstract}
The reduction of the sintering temperature of doped ceria ceramics remains an open challenge for their real exploitation as electrolytes for intermediate temperature solid oxide fuel cell (IT-SOFCs) at the industrial level. In this work, we have used Bi $(0.5$ and $2 \mathrm{~mol} \%)$ as the sintering aid for Gd (20 mol \%)-doped ceria. Nano-sized powders of Bi/Gd co-doped ceria were easily synthesized via a simple and cheap sol-gel combustion synthesis. The obtained powders showed high sinterability and very good electrochemical properties. More importantly, even after prolonged annealing at $700{ }^{\circ} \mathrm{C}$, both of the powders and of the sintered pellets, no trace of structural modifications, phase instabilities, or Bi segregation appeared. Therefore, the use of a small amount of Bi can be taken into account for preparing ceria-based ceramic electrolytes at low sintering temperatures.
\end{abstract}

Keywords: bismuth; doped-ceria electrolytes; IT-SOFCs; morphology; sintering aid; phase stability

\section{Introduction}

Ceria $\left(\mathrm{CeO}_{2}\right)$-based ceramics doped with rare earth metal-oxides are established electrolytes for intermediate temperature solid oxide fuel cells (IT-SOFCs), due to their well-known ionic properties and compatibility with state-of-the-art electrode materials [1-3]. To produce ceria-based electrolytes with both adequate densities and desirable ionic conductivity, high sintering temperatures are required. Consequently, the high manufacturing costs are still a limit for SOFC commercialization [4]. The development of new electrolyte materials is particularly crucial for lowering sintering temperatures. In fact, if a dense electrolyte could be prepared at low temperatures, it could be co-sintered with the electrode components for solid oxide fuel cell applications $[5,6]$. The reduction of sintering temperature, leading to the reduction of energy consumption, can be achieved by adding metal additives to ceria doped electrolytes during synthesis [7-13], by synthesizing very reactive powder with ideal morphology as the ones obtained via hydrothermal treatment [14], or by using innovative sintering methods as Flash Sintering [15] or Fast Firing [16]. The first approach can improve both electrochemical and microstructural properties with an effective reduction of sintering temperature [17-19]. Among the many possible SOFC electrolytes reported in the literature, bismuth oxide with a fluorite-like structure $\left(\delta-\mathrm{Bi}_{2} \mathrm{O}_{3}\right)$ exhibits the highest oxygen ionic conductivity $[1,20]$ due to the combination of a high concentration of oxygen vacancies (around 25\%) and greater anion mobility [21]. Nevertheless, the use of pure $\delta-\mathrm{Bi}_{2} \mathrm{O}_{3}$ is limited to a very narrow temperature range: $730-824^{\circ} \mathrm{C}$. In fact, pure $\delta-\mathrm{Bi}_{2} \mathrm{O}_{3}$ 
melts above $824{ }^{\circ} \mathrm{C}$ and, upon cooling below $730{ }^{\circ} \mathrm{C}$, the transition from the $\delta$-cubic phase to either the metastable tetragonal $\beta$-phase, the body-centered cubic (BCC) $\gamma$-phase, or the monoclinic $\alpha$-phase [22], takes place, thus resulting in a discontinuous drop in ionic conduction and in an unfavorable increase of the electronic conductivity $[23,24]$. To stabilize the $\delta-\mathrm{Bi}_{2} \mathrm{O}_{3}$ phase, the doping with another oxide in tetravalent $\left(\mathrm{CeO}_{2}\right)$ or trivalent systems $\left(\mathrm{CeO}_{2}-\mathrm{Gd}_{2} \mathrm{O}_{3}\right)$ with appropriate compositions is strictly necessary.

It is reported in literature that the solubility of $\mathrm{Bi}^{3+}$ in $\mathrm{CeO}_{2}$ lattice and the probability of obtaining a pure single-phase solid solution of $\mathrm{CeO}_{2}-\mathrm{Bi}_{2} \mathrm{O}_{3}$, is highly dependent on synthesis condition, as well as on the temperature. Many synthesis routes have been proposed to obtain stable single-phase co-doped ceria solid solutions as, for example, solid-state reaction, hydrothermal synthesis, PVA polymerization process, hydrothermal treatment, and co-precipitation routes [25-30]. Since the substitutional solid solution of $\mathrm{Bi}_{2} \mathrm{O}_{3}$ in $\mathrm{CeO}_{2}$ violates the well-known Hume-Rothery's rules, a limited solubility is expected for doped and co-doped ceria systems. For example, Dikmen et al. [31] performed hydrothermal synthesis at $260^{\circ} \mathrm{C}$ reaching a solubility limit of $\mathrm{Bi}$ in $\mathrm{CeO}_{2}$ around $20 \mathrm{~mol} \%$. Other authors $[27,30]$ achieved a solubility up to $10 \%$ or $15 \%$ only after calcination between $500-800{ }^{\circ} \mathrm{C}$, while Chen and Eysel [26] investigated several $\mathrm{Bi}_{2} \mathrm{O}_{3}$-ceria systems without finding a fluorite structure after solid-state reaction and firing at $830{ }^{\circ} \mathrm{C}$ in samples containing 0 to $40 \mathrm{~mol} \%$ of $\mathrm{Bi}_{2} \mathrm{O}_{3}$.

Prekasky et al. [32] synthesized a nanocrystalline $\mathrm{CeO}_{2}-\mathrm{Bi}_{2} \mathrm{O}_{3}$ electrolyte by a self-propagating room temperature procedure, pointing out that all samples with a bismuth concentration higher than 10 at $\%$ were unstable during thermal treatments. Additionally, they detected the formation of $\beta-\mathrm{Bi}_{2} \mathrm{O}_{3}$ as secondary phase above $700{ }^{\circ} \mathrm{C}$ and the evaporation of bismuth at temperatures above $1200{ }^{\circ} \mathrm{C}$.

Gil et al. [29,33] doped $\mathrm{Ce}_{0.9} \mathrm{Gd}_{0.1} \mathrm{O}_{1.95}$ with different amounts of bismuth oxide $(0.2-2 \mathrm{wt} \%)$ via the solid-state reaction route. The solubility limit of the cubic-structured $\mathrm{Bi}_{2} \mathrm{O}_{3}$ was found to be about $0.8 \mathrm{wt} \%$, but its structural stability was not fully investigated.

Since ceria-based ceramics co-doped with bismuth are becoming conveniently and successfully used as electrolytes for IT-SOFCs, it is crucial to investigate their structure and phase stability in the proper temperature range by considering the conflicting results reported in the literature. With these considerations in mind, in this work we studied the effect of two small amounts of bismuth ( 0.5 and $2 \mathrm{~mol} \%$ ) to gadolinium-doped ceria electrolytes prepared by a cheap and fast sol-gel combustion synthesis, mainly aiming to verify the long-term stability of the synthesized products and their electrochemical behavior. The adopted synthesis route was already successfully used to produce other $\mathrm{CeO}_{2}$-based nanopowders $[17,34,35]$. Compared to the conventional solid-state route, sol-gel combustion synthesis is mostly suitable for IT-SOFC applications due to the high chance of producing very reactive and easily sinterable electrolyte powders, generally nano-sized with regular morphology. In fact, the formation of nano-sized powders is promoted by the molecular mixing of all precursors. Thermal stability of the solid solution was evaluated after thermal treatment of powders at $700{ }^{\circ} \mathrm{C}$ for $100 \mathrm{~h}$. Powders were characterized by X-ray diffraction (XRD) and scanning electron microscopy (SEM) techniques. The morphology of sintered pellets was inspected by SEM and energy-dispersive X-ray spectroscopy (EDS), while their electrochemical properties were measured by electrochemical impedance spectroscopy (EIS).

\section{Results and Discussion}

The sol-gel combustion synthesis method allows the direct formation of Bi/Gd co-doped ceria, inasmuch as all the transformations occurred during such a process can be represented by the following global reaction. For simplicity the reaction is written with Ce as the only cation, whilst there is actually a mixture of different cations according to the compositions reported in Table 1:

$$
9 \mathrm{Ce}\left(\mathrm{NO}_{3}\right)_{3}+7 \mathrm{C}_{6} \mathrm{H}_{8} \mathrm{O}_{7} \cdot \mathrm{H}_{2} \mathrm{O} \rightarrow 9 \mathrm{CeO}_{2}+\frac{27}{2} \mathrm{~N}_{2}+42 \mathrm{CO}_{2}+35 \mathrm{H}_{2} \mathrm{O}
$$


Table 1. Synthesized samples, composition, and Bi content.

\begin{tabular}{ccc}
\hline Sample & Composition & Bi (mol \%) \\
\hline $0.5 \mathrm{Bi}$ & $\mathrm{Bi}_{0.005} \mathrm{Ce}_{0.796} \mathrm{Gd}_{0.199} \mathrm{O}_{1.898}$ & 0.5 \\
$2 \mathrm{Bi}$ & $\mathrm{Bi}_{0.02} \mathrm{Ce}_{0.784} \mathrm{Gd}_{0.196} \mathrm{O}_{1.892}$ & 2 \\
\hline
\end{tabular}

The nominal compositions and the labels of the two samples investigated are reported in the following Table 1.

Nanometric powders of $\mathrm{Bi} / \mathrm{Gd}$ co-doped ceria are directly formed via sol-gel combustion process. The diffraction patterns of the as-synthesized samples $0.5 \mathrm{Bi}$ and $2 \mathrm{Bi}$ are presented in Figure 1 ; the aspect of these patterns suggests that both the as-synthesized samples are partially amorphous and partially crystallized in fluorite-structured doped ceria with broad XRD peaks as usual for the adopted synthesis route. These results suggest that, irrespective of the actual content of $\mathrm{Bi}$, during the synthesis process $\mathrm{Ce}(\mathrm{III})$ is oxidized to $\mathrm{Ce}(\mathrm{IV})$, a fluorite lattice is established in the as-forming solid and Gd and Bi atoms are dissolved in it.

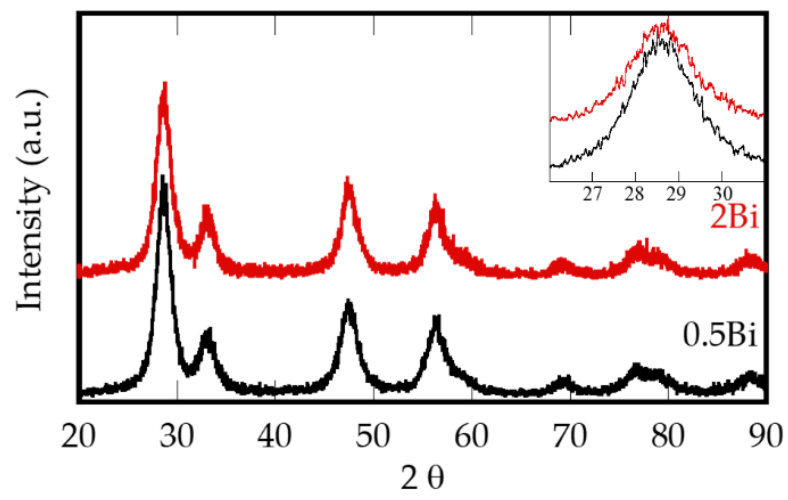

Figure 1. Diffraction patterns of the as-synthesized samples (the inset showing a magnification of spectrum main peak).

To allow the complete crystallization of the fluorite-structured ceria, a calcination step in air was carried out at $600^{\circ} \mathrm{C}$ for $2 \mathrm{~h}$. This relatively low temperature has been selected in order to limit the grain growth. A further calcination step was also carried out for a long time $(100 \mathrm{~h})$ at $700{ }^{\circ} \mathrm{C}$ aiming to simulate the behavior of these materials over long operations in an IT-SOFC. The corresponding diffraction patterns of samples calcined at $600{ }^{\circ} \mathrm{C}$ and $700^{\circ} \mathrm{C}$ are displayed in Figure 2a,b, respectively.

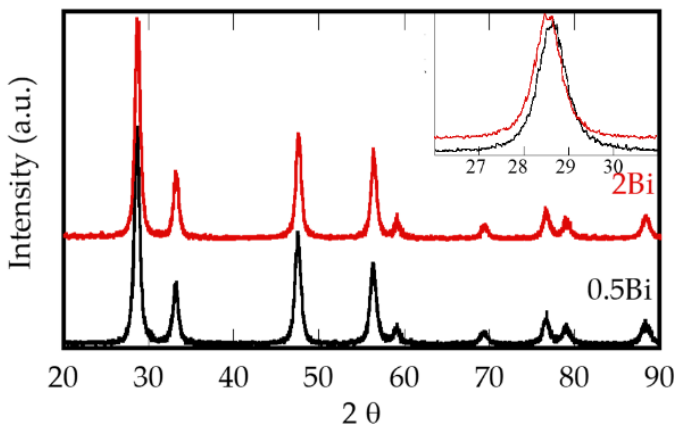

(a)

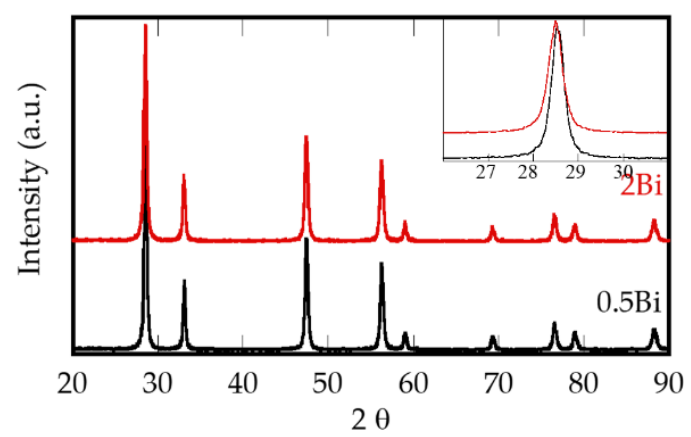

(b)

Figure 2. (a) Diffraction patterns of samples calcined at $600{ }^{\circ} \mathrm{C}$ for $2 \mathrm{~h}$; (b) diffraction patterns of samples calcined at $700{ }^{\circ} \mathrm{C}$ for $100 \mathrm{~h}$ (insets showing magnifications of the spectra main peak).

Both the 0.5Bi and 2Bi samples are well-crystallized in the fluorite-like structure after the calcination treatments and there is no trace of any secondary phase. The absence of any phase transformations, 
even after the prolonged calcination at $700{ }^{\circ} \mathrm{C}$, suggests that the equilibrium condition has been achieved. The only evident difference among the two patterns is, obviously, the stronger sharpness of the XRD peaks of sample calcined at $700{ }^{\circ} \mathrm{C}$ for $100 \mathrm{~h}$; in particular, compare the insets in Figure 2a,b. The lattice parameter of samples after the two different calcination steps, determined by Rietveld refinement, are displayed in Table 2, along with their crystal size.

Table 2. Lattice parameter and crystal size of calcined samples.

\begin{tabular}{cccc}
\hline Sample & Calcination Temperature & Lattice Parameter $\boldsymbol{a}(\mathbf{n m})$ & Crystal Size (nm) \\
\hline $0.5 \mathrm{Bi}$ & $600^{\circ} \mathrm{C}$ & $0.54284(5)$ & $18.7(2)$ \\
$2 \mathrm{Bi}$ & $600^{\circ} \mathrm{C}$ & $0.54274(4)$ & $19.6(2)$ \\
$0.5 \mathrm{Bi}$ & $700^{\circ} \mathrm{C}$ & $0.54270(2)$ & $50.9(4)$ \\
$2 \mathrm{Bi}$ & $700^{\circ} \mathrm{C}$ & $0.54262(2)$ & $43.3(3)$ \\
\hline
\end{tabular}

The very similar lattice parameters displayed in Table 2 are slightly larger than the theoretical one of $\mathrm{Gd}$ (20 mol \%)-doped $\mathrm{CeO}_{2}$ (see ICCD card n. 75-0162) and the one related to Gd (20 mol $\%$ )-doped $\mathrm{CeO}_{2}$ synthesized with exactly the same sol-gel combustion synthesis [17]. These findings, combined with the absence of any secondary phases in all the presented diffraction patterns, prove further the complete dissolution of $\mathrm{Bi}^{3+}$ cations inside the fluorite-like lattice, being the size of $\mathrm{Bi}^{3+}$ cation $\left(0.117 \mathrm{~nm}\right.$ in eightfold coordination) larger than both $\mathrm{Ce}^{4+}(0.097 \mathrm{~nm}$ in eightfold coordination) and $\mathrm{Gd}^{3+}(0.1053 \mathrm{~nm}$ in eightfold coordination), thus causing the expansion of the unit cell, according to the substitutional defect formation represented by the following equation in Kroger-Vink notation:

$$
\mathrm{Bi}_{2} \mathrm{O}_{3} \rightarrow 2 \mathrm{Bi}_{\mathrm{Ce}}^{\prime}+3 \mathrm{O}_{\mathrm{O}}^{x}+\mathrm{V}_{\mathrm{O}}^{*}
$$

On the other hand, there is a remarkable difference in the crystal size for both samples after the two calcination steps. This is perfectly justifiable on the base of the grain growth processes caused by the prolonged thermal treatment at $700{ }^{\circ} \mathrm{C}$.

Finally, the true (theoretical) density $\rho$ of the samples is calculated by following Equation (3):

$$
\rho=\frac{Z \sum_{i} v_{i} \cdot M_{i}}{a^{3} \cdot N_{A}}
$$

where $\mathrm{Z}$ is the number of formula units per unit cell (four for the fluorite structure), $v_{\mathrm{i}}$ is the stoichiometric coefficient of the element $i$ in the chemical formula, $\mathrm{M}_{\mathrm{i}}$ is the molar mass in $\mathrm{g} \cdot \mathrm{mol}^{-1}$ of the element $i, a$ is the lattice parameter reported in Table 2 (related to the prolonged calcination at $700{ }^{\circ} \mathrm{C}$ ) and $\mathrm{N}_{\mathrm{A}}$ is the Avogadro's constant. The calculated true densities are 7.241 and $7.277 \mathrm{~g} / \mathrm{cm}^{3}$, for $0.5 \mathrm{Bi}$ and $2 \mathrm{Bi}$, respectively, which will be used in the following for calculating the samples relative densities.

The powders calcined at $600{ }^{\circ} \mathrm{C}$ for $2 \mathrm{~h}$ were uniaxially pressed and then sintered at $1250{ }^{\circ} \mathrm{C}$ for $3 \mathrm{~h}$ using $5{ }^{\circ} \mathrm{C} / \mathrm{min}$ as the heating rate. The green density of as-pressed pellets was 2.09 and $2.40 \mathrm{~g} / \mathrm{cm}^{3}$ for $0.5 \mathrm{Bi}$ and $2 \mathrm{Bi}$, respectively, corresponding to approx. $30 \%$ of the theoretical density (i.e., a rather low value). On the contrary, the relative densities of the sintered pellets were about $93 \%$ and $96 \%$ for $0.5 \mathrm{Bi}$ and $2 \mathrm{Bi}$, respectively. Therefore, despite the rather low green densities, very high final densities have been achieved by sintering them at a relatively low temperature, especially for the sample $2 \mathrm{Bi}$. These results strongly suggest that Bi acted as a very efficient sintering aid.

Two exemplary micrographs of the sintered samples are shown in Figure 3, confirming the high value of their measured densities. Both samples own very similar microstructures, showing a good level of densification, especially for the sample 2Bi. In fact, only a small amount of microporosity located at the grain boundaries can be noticed in sample 2Bi. The grain structure appears well-homogeneous for both the samples, with the presence of equiaxed grains, whose size is in the order of some hundreds of nanometers (the average grain size is $280 \mathrm{~nm}$ and $250 \mathrm{~nm}$ for $0.5 \mathrm{Bi}$ and 2Bi, respectively) as it can be evaluated in the two insets at higher magnification reported in Figure 3. 

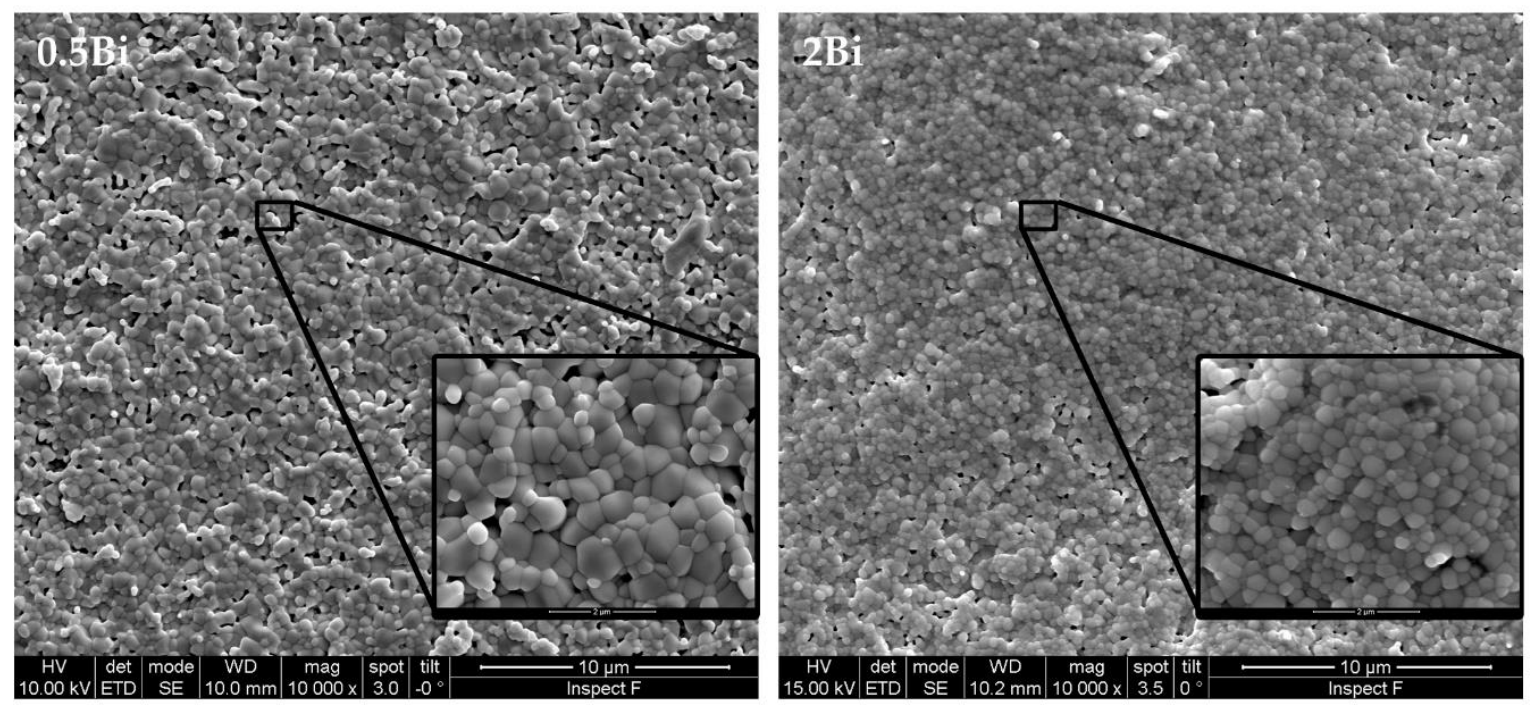

Figure 3. SEM micrographs of samples $0.5 \mathrm{Bi}$ and $2 \mathrm{Bi}$ sintered at $1250{ }^{\circ} \mathrm{C}$ for $3 \mathrm{~h}$.

As stated above, the presence of the Bi sintering aid is the key factor to obtain these very good microstructures. However, when additives are used, it can be useful to study their distribution over the surface of the material, since an inhomogeneous presence of them, as for example, their accumulation along the grain boundaries, could impair the physical properties (especially the electrical properties). Thus, a mapping of the chemical elements' distribution, obtained by EDS, was carried out for the best sample, i.e., $2 \mathrm{Bi}$, and the corresponding results are shown in Figure 4 . Bi is represented by yellow spots, Ce by fuchsia spots, Gd by cyan spots and $\mathrm{O}$ by light green spots. The homogeneous distribution of all the elements is evident (see Figure 4 b). In addition, for sake of clarity, the distribution of only Bi is displayed in Figure 4c. These observations clearly suggest that no phase segregation occurred upon the sintering step. Therefore, it is inferred that the microstructure of the sintered samples is nearly ideal for obtaining very good electrochemical properties, especially for sample 2Bi.
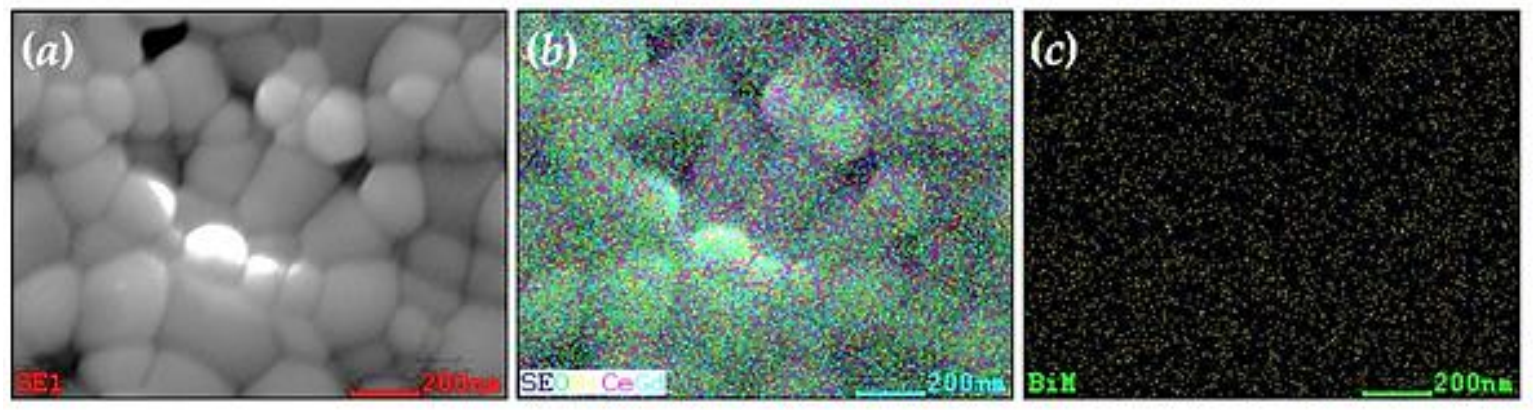

Figure 4. Elements mapping by EDS of sample 2Bi sintered at $1250{ }^{\circ} \mathrm{C}$ for $3 \mathrm{~h}$ : (a) area of the sample, (b) mapping of all elements and (c) mapping of Bi.

Then, electrochemical properties of both sintered samples were investigated. Impedance data were analyzed using an equivalent circuit with three-sub circuits joined together in series representing the electrode $\left(\mathrm{R}_{\mathrm{el}}-\mathrm{CPE}\right)$, the grain interior $\left(\mathrm{R}_{\mathrm{b}}-\mathrm{CPE}\right)$, and the grain boundary $\left(\mathrm{R}_{\mathrm{gb}}-\mathrm{CPE}\right)$ contributions. $\mathrm{CPE}$ is the constant phase element, corresponding to a variable capacitance value, while the resistances $R_{b}, R_{g b}$, and $R_{e l}$ are the bulk, grain boundary, and electrode resistances, respectively. The three resistances are used to estimate the total conductivity based on the shape of the Nyquist plot and the geometrical dimensions of the electrolyte. Two representative examples of Nyquist plot, at $750{ }^{\circ} \mathrm{C}$ and $400{ }^{\circ} \mathrm{C}$, for the $0.5 \mathrm{Bi}$ and $2 \mathrm{Bi}$ are reported in Figure 5. 

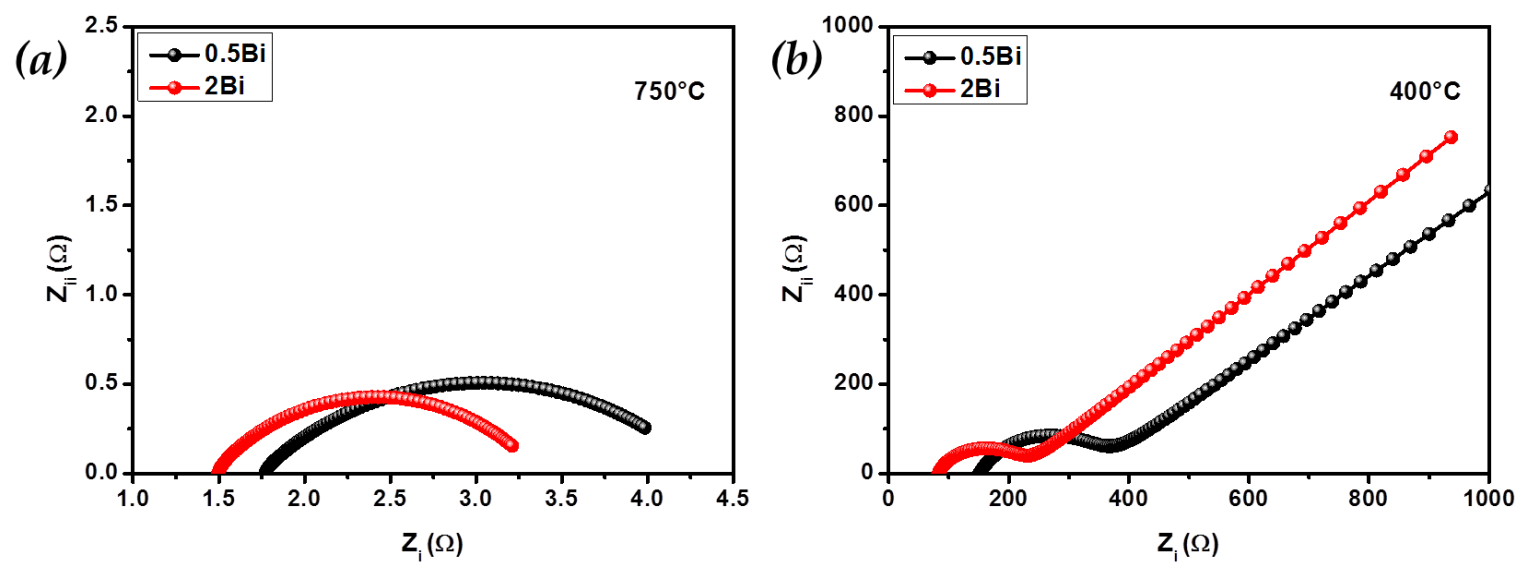

Figure 5. Nyquist plots of the sintered samples (a) $750{ }^{\circ} \mathrm{C}$; (b) $400{ }^{\circ} \mathrm{C}$. The different shape of the spectra requires two different fitting circuits.

At high temperature $\left(800-550^{\circ} \mathrm{C}\right)$, the response is characterized only by the electrode contribution (see Nyquist plots in Figure 5a) because bulk and grain boundaries are too weak to be analyzed and the model fits the impedance data with a simple circuit, $L \cdot R_{t} \cdot\left(R_{e l}-C P E\right)$, where $R_{t}$ corresponds to the total internal resistance and $\mathrm{L}$ is the instrumental inductance, if any.

The total conductivity values are illustrated in Figure 6a as a function of temperature. Data cannot be fitted with a single straight line due to the presence of a change in the slope for the occurrence of grain boundary contribution around $500{ }^{\circ} \mathrm{C}$. Not surprisingly, conductivity increases with bismuth content, very likely due to better densification and larger amounts of oxygen vacancies. The improvement in the total conductivity is clearly evident in the low-temperature regime $\left(500-200{ }^{\circ} \mathrm{C}\right)$ where grain boundary contribution can be detected as visible in the Nyquist plots of Figure $5 \mathrm{~b}$. In this temperature range, the grain boundary conductivity of $2 \mathrm{Bi}$ is more than two times higher than $0.5 \mathrm{Bi}$ until $400{ }^{\circ} \mathrm{C}$ and one order of magnitude higher at $200-300{ }^{\circ} \mathrm{C}$. The effective grain boundary conductivity was calculated according to the following equation:

$$
\sigma_{G B}^{e f f}=\frac{s}{R_{G B} \cdot A_{e l}}
$$

where $\mathrm{s}$ is the electrolyte thickness, $\mathrm{R}_{\mathrm{GB}}$ is the resistance at grain boundary, and $\mathrm{A}_{\mathrm{el}}$ is the electrode area.
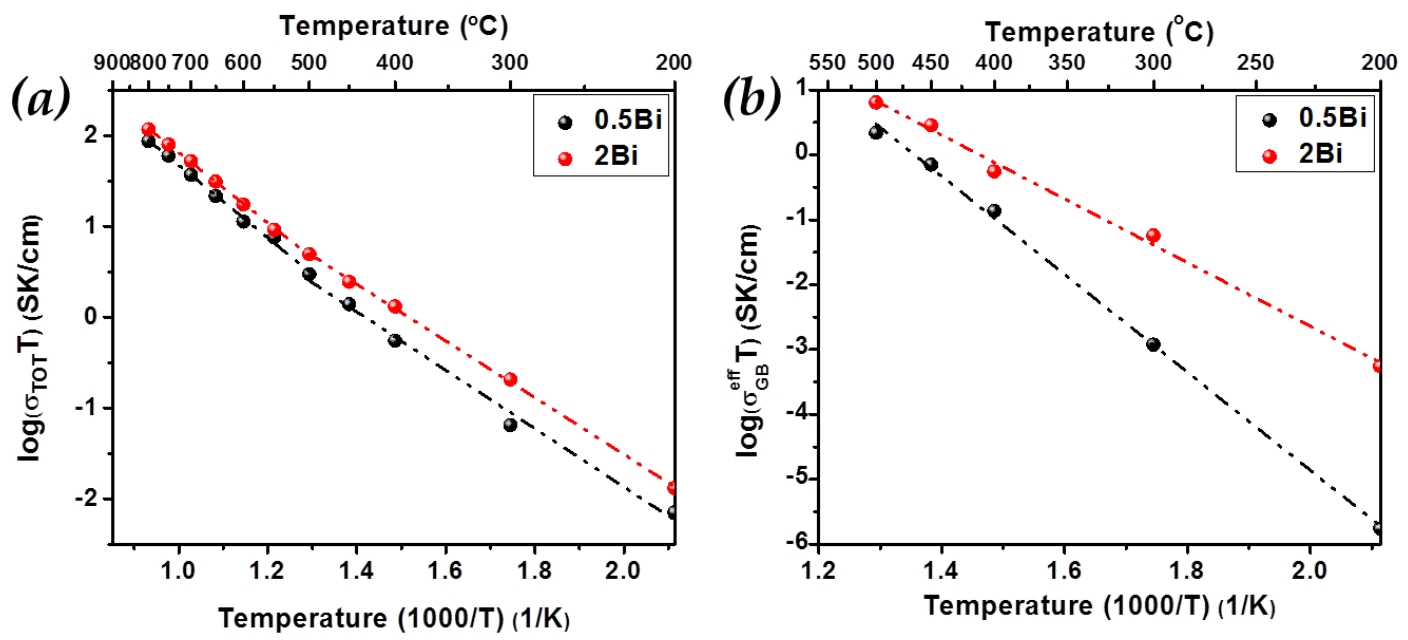

Figure 6. Arrhenius plots from EIS spectra of the sintered samples: (a) total conductivity $\left(800-200{ }^{\circ} \mathrm{C}\right)$; (b) grain boundary conductivity $\left(500-200{ }^{\circ} \mathrm{C}\right)$. 
As visible in Figure 6, the activation energy in the grain boundary region decreases with bismuth content indicating an improvement of the total conductivity. The values of total conductivities and the activation energies are summarized in Table 3.

Table 3. Total conductivities $(\sigma)$ and activation energies $\left(E_{a}\right)$.

\begin{tabular}{|c|c|c|}
\hline$\sigma / E_{a}$ & $0.5 \mathrm{Bi}$ & $2 B i$ \\
\hline $\mathrm{E}_{\mathrm{a}}\left(T \leq 500^{\circ} \mathrm{C}\right)(\mathrm{eV})$ & 0.63 & 0.61 \\
\hline $\mathrm{E}_{\mathrm{a}}\left(T \geq 500^{\circ} \mathrm{C}\right)(\mathrm{eV})$ & 0.79 & 0.76 \\
\hline $\mathrm{E}_{\mathrm{a}(\mathrm{gb})}(\mathrm{eV})$ & 1.49 & 0.97 \\
\hline$\sigma_{\left(400{ }^{\circ} \mathrm{C}\right)}\left(\mathrm{S} \cdot \mathrm{cm}^{-1}\right)$ & $1.62 \times 10^{-4}$ & $4.86 \times 10^{-4}$ \\
\hline$\sigma_{\left(500^{\circ} \mathrm{C}\right)}\left(\mathrm{S} \cdot \mathrm{cm}^{-1}\right)$ & $2.12 \times 10^{-3}$ & $3.62 \times 10^{-3}$ \\
\hline$\sigma_{\left(550^{\circ} \mathrm{C}\right)}\left(\mathrm{S} \cdot \mathrm{cm}^{-1}\right)$ & $6.65 \times 10^{-3}$ & $1.10 \times 10^{-2}$ \\
\hline$\sigma_{\left(600^{\circ} \mathrm{C}\right)}\left(\mathrm{S} \cdot \mathrm{cm}^{-1}\right)$ & $1.29 \times 10^{-2}$ & $1.99 \times 10^{-2}$ \\
\hline$\sigma_{\left(650^{\circ} \mathrm{C}\right)}\left(\mathrm{S} \cdot \mathrm{cm}^{-1}\right)$ & $2.33 \times 10^{-2}$ & $3.37 \times 10^{-2}$ \\
\hline$\sigma_{\left(70{ }^{\circ} \mathrm{C}\right)}\left(\mathrm{S} \cdot \mathrm{cm}^{-1}\right)$ & $3.80 \times 10^{-2}$ & $5.39 \times 10^{-2}$ \\
\hline$\sigma_{\left(750^{\circ} \mathrm{C}\right)}\left(\mathrm{S} \cdot \mathrm{cm}^{-1}\right)$ & $5.87 \times 10^{-2}$ & $7.81 \times 10^{-2}$ \\
\hline$\sigma_{\left(800^{\circ} \mathrm{C}\right)}\left(\mathrm{S} \cdot \mathrm{cm}^{-1}\right)$ & $8.11 \times 10^{-2}$ & $1.10 \times 10^{-1}$ \\
\hline
\end{tabular}

Finally, we verified if the microstructure of samples were not impaired after long-run operations. Therefore, a prolonged thermal treatment at $700{ }^{\circ} \mathrm{C}$ for $100 \mathrm{~h}$ was carried on $2 \mathrm{Bi}$ sintered pellet, and its microstructure along with Bi distribution was analyzed again. The corresponding SEM micrographs are presented in Figure 7a,b.

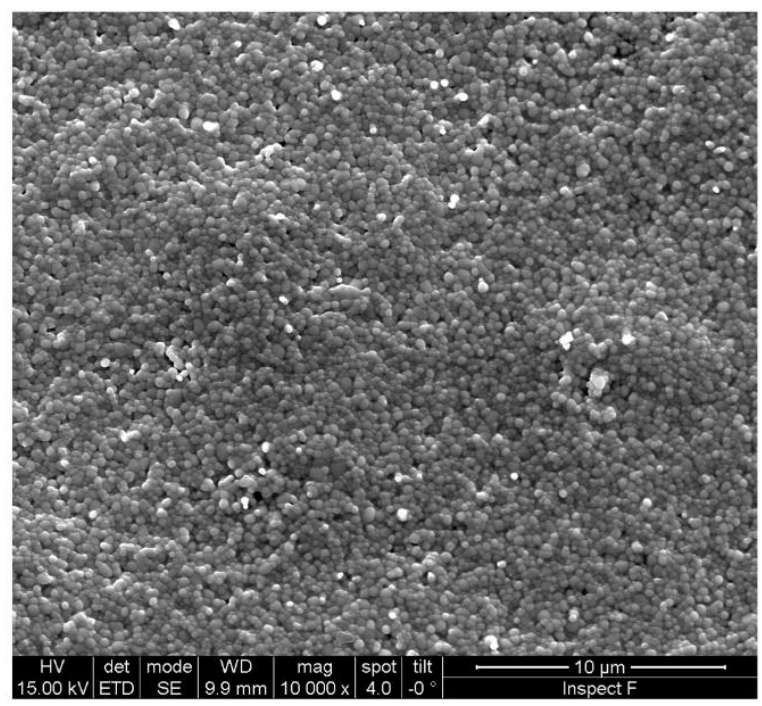

(a)

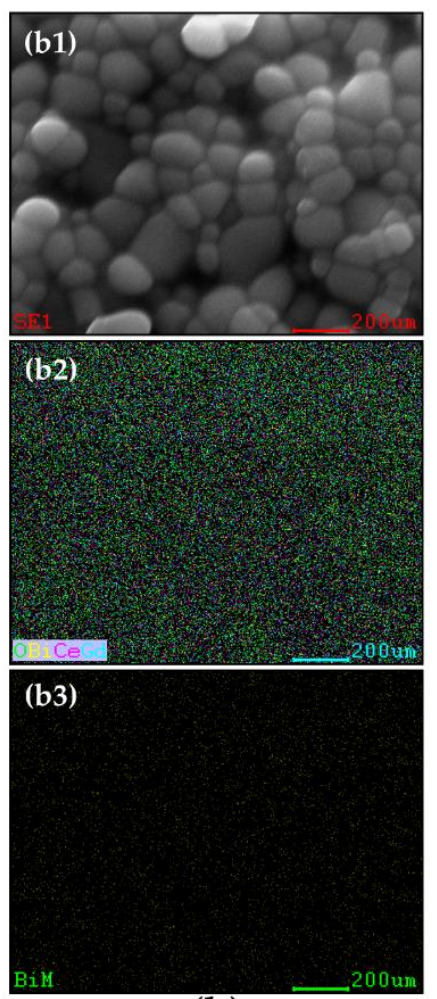

(b)

Figure 7. (a) SEM micrograph and (b) Elements mapping by EDS of sample $2 \mathrm{Bi}$ sintered at $1250{ }^{\circ} \mathrm{C}$ for $3 \mathrm{~h}$ after exposure for $100 \mathrm{~h}$ at $700{ }^{\circ} \mathrm{C}$.

The morphology of the sample is very similar to the one showed by the sample 2Bi in Figure 3, thus indicating that the grain growth, due to the prolonged thermal treatment, is minimal, being the average grain size about $270 \mathrm{~nm}$, only slightly higher than the one corresponding to sample 2Bi in Figure $3(250 \mathrm{~nm})$. Furthermore, the Bi distribution (indicated by yellow spots) has not been altered. 
Based on the reported results, it can be concluded that the presence of a small amount of Bi speeded up the sintering process of ceria-based electrolytes in a significant way, so that a very good densification can also be achieved at a reduced sintering temperature, i.e., $1250{ }^{\circ} \mathrm{C}$ (with Bi equal to $2 \mathrm{~mol} \%$ ), without impairing neither their microstructure nor their electrochemical properties, even after very prolonged thermal treatments, simulating SOFCs long run operations. The EDS microanalysis suggests that there is no segregation or a solubility limitation of $\mathrm{Bi}$ in the co-doped solid solution with Ce and Gd oxides for the amounts investigated giving, therefore, a piece of important evidence with respect to the reported literature in this field where solubility limits were detected for lower equivalent contents of $\mathrm{Bi}$, but adopting inefficient or not optimized synthesis routes.

\section{Materials and Methods}

Bismuth-doped ceria nanopowders were synthesized via one-step sol-gel combustion synthesis starting from high purity precursors of cerium nitrate hexahydrate $\left(\mathrm{Ce}\left(\mathrm{NO}_{3}\right)_{3} \cdot 6 \mathrm{H}_{2} \mathrm{O},>99.0 \%\right.$ purity) and gadolinium nitrate hexahydrate $\left(\mathrm{Gd}\left(\mathrm{NO}_{3}\right)_{3} \cdot 6 \mathrm{H}_{2} \mathrm{O},>99.0 \%\right.$ purity). Citric acid monohydrate $\left(\mathrm{C}_{6} \mathrm{H}_{8} \mathrm{O}_{7} \cdot \mathrm{H}_{2} \mathrm{O},>99.0 \%\right.$ purity $)$ was used as a complexing agent. Additional details of the synthesis conditions are reported elsewhere [32]. After the dissolution of these precursors in a limited amount of water, the amounts corresponding to the 0.5 and $2 \mathrm{~mol} \%$ of bismuth nitrate $\left(\mathrm{Bi}\left(\mathrm{NO}_{3}\right)_{3} \cdot 5 \mathrm{H}_{2} \mathrm{O},>99.0 \%\right.$ purity) were directly added at this stage before starting the sol-gel reaction to reduce the synthesis time and to promote the molecular mixing of all precursors. The as-obtained powders were calcined at $600^{\circ} \mathrm{C}$ in air for $2 \mathrm{~h}$ before the subsequent characterizations. All reagents were purchased from Sigma Aldrich (St. Louis, MO, USA) and used as received, without any further purification.

The crystalline nature of the as-prepared powders and calcined samples were ascertained by X-ray diffraction using a Miniflex II, (Rigaku Co diffractometer, Seoul, South Korea) (Cu K $\alpha$ radiation, $2 \theta$ range $20-90^{\circ}$ ). To evaluate the formation of additional phases and the stability of crystal structure, the synthesized powders were firstly thermally treated at $700{ }^{\circ} \mathrm{C}$ for $100 \mathrm{~h}$ and then characterized by $\mathrm{XRD}$ analysis. This calcination temperature was selected being it the standard operating temperature of IT-SOFCs. The lattice parameters and the crystal size were calculated by Rietveld refinement by using MAUD suite [36].

The samples calcined at $600^{\circ} \mathrm{C}$ were uniaxially pressed at $200 \mathrm{MPa}$ in a $15 \mathrm{~mm}$-diameter stainless steel mold and then sintered at $1250^{\circ} \mathrm{C}$ in air by using $5^{\circ} \mathrm{C} / \mathrm{min}$ as the heating rate to obtain dense pellets with a diameter of approx. $10 \mathrm{~mm}$ and variable thicknesses, depending on sintering behavior and final shrinkage. The relative densities of both green and sintered pellets were determined through Archimedes' principle by using a hydrostatic balance.

Morphology, grain size, and distribution of the various elements were analyzed by SEM (Inspect F, FEI Co., Hillsboro, OR, USA USA) coupled with an EDS analyzer. Average grain size of the various sintered samples were estimated by using the average grain intercept method.

The electrochemical properties of the sintered pellets were measured by using a frequency response analyzer (FRA, Solartron 1260) (Ametek, UK) coupled with a dielectric interface (Solartron 1296) in a frequency range between $0.1 \mathrm{~Hz}$ and $1 \mathrm{MHz}, \mathrm{AC}$ voltage amplitude of $10 \mathrm{mV}$, and in the temperature $800-200{ }^{\circ} \mathrm{C}$.

\section{Conclusions}

Nanosized particles of $\mathrm{Gd}$ and Bi co-doped ceria were synthesized via a cheap and simple sol-gel combustion process. Both $\mathrm{Bi}$ and $\mathrm{Gd}$ are entirely and homogeneously dissolved into ceria fluorite-like structure, forming an equilibrium phase, so that also after very prolonged thermal treatment, no Bi-related phase transformation occurred. Moreover, the presence of Bi eased the sintering process allowing achieving very good densification levels (relative density equal to $96 \%$ for the sample containing $2 \mathrm{~mol} \%$ of Bi) by firing the obtained pellets at $1250^{\circ} \mathrm{C}$ for $3 \mathrm{~h}$. The electrochemical properties of the sample $2 \mathrm{Bi}$ within the range $550^{\circ} \mathrm{C}-800^{\circ} \mathrm{C}$ indicate that this electrolyte is suitable 
for applications in IT-SOFC $\left(1.1 \times 10^{-2}-1.1 \times 10^{-1} \mathrm{~S} / \mathrm{cm}\right)$. Finally, we demonstrated that also for the sintered pellets no phase transformations occurred as a result of prolonged thermal treatments at $700{ }^{\circ} \mathrm{C}$.

Definitely, we proved that by adding a small amount of Bi to gadolinium-doped ceria ceramics it is possible to obtain an equilibrium solid solution with the fluorite-like matrix, at the same time remarkably improving sinterability and electrochemical properties.

Author Contributions: Conceptualization, G.D. and G.A.; Methodology, L.S. and D.F.; formal analysis, G.D. and L.S.; investigation, G.A. and D.F.; resources, S.P.Y., G.D. and G.A.; writing-original draft preparation, G.D., D.F. and G.A.; writing-review and editing, S.P.Y. and L.S.; visualization, L.S. and D.F.; supervision, S.P.Y. and G.D.; project administration, S.P.Y.; funding acquisition, G.A.

Funding: Grazia Accardo was supported by the Korea Research Fellowship Program through the National Research Foundation of Korea (NRF) funded by the Ministry of Science and ICT (Grant Number: 2016H1D3A1908428).

Conflicts of Interest: The authors declare no conflict of interest.

\section{References}

1. Zhang, Y.; Knibbe, R.; Sunarso, J.; Zhong, Y.; Zhou, W.; Shao, Z.; Zhu, Z. Recent Progress on Advanced Materials for Solid-Oxide Fuel Cells Operating Below $500{ }^{\circ} \mathrm{C}$. Adv. Mater. 2017, 29, 1700132. [CrossRef] [PubMed]

2. Wang, P.; Wang, J.; Fu, L.; Wu, Y.; van Ree, T. Metal oxides in fuel cells. In Metal Oxides in Energy Technologies; Wu, Y., Ed.; Elsevier: Amsterdam, The Netherlands, 2018; pp. 17-47.

3. Dell'Agli, G.; Spiridigliozzi, L.; Pansini, M.; Accardo, G.; Yoon, S.P.; Frattini, D. Effect of the carbonate environment on morphology and sintering behaviour of variously co-doped (Ca, Sr, Er, Pr) Samarium-doped Ceria in co-precipitation/hydrothermal synthesis. Ceram. Int. 2018, 44, 17935-17944. [CrossRef]

4. Shao, Z.; Tadé, M.O. Application of SOFC Technology. In Energy Technology 2016; Springer International Publishing: Cham, Switzerland, 2016; pp. 247-266.

5. De Marco, V.; Grazioli, A.; Sglavo, V.M. Production of planar copper-based anode supported intermediate temperature solid oxide fuel cells cosintered at $950{ }^{\circ} \mathrm{C}$. J. Power Sources 2016, 328, 235-240. [CrossRef]

6. De Marco, V.; Iannaci, A.; Rashid, S.; Sglavo, V.M. Effect of anode thickness and Cu content on consolidation and performance of planar copper-based anode-supported SOFC. Int. J. Hydrogen Energy 2017, 42, 12543-12550. [CrossRef]

7. Gil, V.; Moure, C.; Durán, P.; Tartaj, J. Low-temperature densification and grain growth of $\mathrm{Bi}_{2} \mathrm{O}_{3}$-doped-ceria gadolinia ceramics. Solid State Ion. 2007, 178, 359-365. [CrossRef]

8. Kumar, K.; Singh, N.K.; Park, H.-S.; Parkash, O. Doping effect of copper ion $\left(\mathrm{Cu}^{2+}\right)$ on the conductivity behaviour of ceria $\left(\mathrm{Ce}_{1-x} \mathrm{Cu}_{x} \mathrm{O}_{1-\delta}\right)$ electrolyte. RSC Adv. 2016, 6, 49883-49890. [CrossRef]

9. Ali, S.A.M.; Anwar, M.; Abdalla, A.M.; Somalu, M.R.; Muchtar, A. $\mathrm{Ce}_{0.80} \mathrm{Sm}_{0.10} \mathrm{Ba}_{0.05} \mathrm{Er}_{0.05} \mathrm{O}_{2-\delta}$ multi-doped ceria electrolyte for intermediate temperature solid oxide fuel cells. Ceram. Int. 2017, 43, 1265-1271. [CrossRef]

10. Ayawanna, J.; Wattanasiriwech, D.; Wattanasiriwech, S.; Aungkavattana, P. Effects of cobalt metal addition on sintering and ionic conductivity of $\mathrm{Sm}(\mathrm{Y})$-doped ceria solid electrolyte for SOFC. Solid State Ion. 2009, 180, 1388-1394. [CrossRef]

11. Nicholas, J.D.; De Jonghe, L.C. Prediction and evaluation of sintering aids for Cerium Gadolinium Oxide. Solid State Ion. 2007, 178, 1187-1194. [CrossRef]

12. Spiridigliozzi, L.; Dell'Agli, G.; Marocco, A.; Accardo, G.; Pansini, M.; Yoon, S.P.; Ham, H.C.; Frattini, D. Engineered co-precipitation chemistry with ammonium carbonate for scalable synthesis and sintering of improved $\mathrm{Sm}_{0.2} \mathrm{Ce}_{0.8} \mathrm{O}_{1.90}$ and $\mathrm{Gd}_{0.16} \mathrm{Pr}_{0.04} \mathrm{Ce}_{0.8} \mathrm{O}_{1.90}$ electrolytes for IT-SOFCs. J. Ind. Eng. Chem. 2018, 59, 17-27. [CrossRef]

13. Spiridigliozzi, L.; Pinter, L.; Biesuz, M.; Dell'Agli, G.; Accardo, G.; Sglavo, V.M. Gd/Sm-Pr Co-Doped Ceria: A First Report of the Precipitation Method Effect on Flash Sintering. Materials 2019, 12, 1218. [CrossRef] [PubMed]

14. Dell'Agli, G.; Spiridigliozzi, L.; Marocco, A.; Accardo, G.; Frattini, D.; Kwon, Y.; Yoon, S.P. Morphological and crystalline evolution of Sm-(20\% mol)-doped ceria nanopowders prepared by a combined co-precipitation/ hydrothermal synthesis for solid oxide fuel cell applications. Ceram. Int. 2017, 43, 12799-12808. [CrossRef] 
15. Biesuz, M.; Dell'Agli, G.; Spiridigliozzi, L.; Ferone, C.; Sglavo, V.M. Conventional and Field-Assisted Sintering of Nanosized Gd-doped Ceria Synthesized by Co-precipitation. Ceram. Int. 2016, 42, 11766-11771. [CrossRef]

16. Biesuz, M.; Spiridigliozzi, L.; Frasnelli, M.; Dell'Agli, G.; Sglavo, V.M. Rapid densification of Samarium-doped Ceria ceramic with nanometric grain size at 900-1100 ${ }^{\circ}$ C. Mater. Lett. 2017, 190, 17-19. [CrossRef]

17. Accardo, G.; Frattini, D.; Ham, H.C.; Han, J.H.; Yoon, S.P. Improved microstructure and sintering temperature of bismuth nano-doped GDC powders synthesized by direct sol-gel combustion. Ceram. Int. 2018, 44, 3800-3809. [CrossRef]

18. Accardo, G.; Frattini, D.; Ham, H.C.; Yoon, S.P. Direct addition of lithium and cobalt precursors to $\mathrm{Ce}_{0.8} \mathrm{Gd}_{0.2} \mathrm{O}_{1.95}$ electrolytes to improve microstructural and electrochemical properties in IT-SOFC at lower sintering temperature. Ceram. Int. 2019, 45, 9348-9358. [CrossRef]

19. Spiridigliozzi, L.; Dell'Agli, G.; Accardo, G.; Yoon, S.P.; Frattini, D. Electro-morphological, structural, thermal and ionic conduction properties of $\mathrm{Gd} / \mathrm{Pr}$ co-doped ceria electrolytes exhibiting mixed $\mathrm{Pr}^{3+} / \mathrm{Pr}^{4+}$ cations. Ceram. Int. 2019, 45, 4570-4580. [CrossRef]

20. Sanna, S.; Esposito, V.; Christensen, M.; Pryds, N. High ionic conductivity in confined bismuth oxide-based heterostructures. APL Mater. 2016, 4, 121101. [CrossRef]

21. Jung, D.W.; Lee, K.T.; Wachsman, E.D. Terbium and Tungsten Co-doped Bismuth Oxide Electrolytes for Low Temperature Solid Oxide Fuel Cells. J. Korean Ceram. Soc. 2014, 51, 260-264. [CrossRef]

22. Jolley, A.G.; Jayathilake, R.; Wachsman, E.D. Optimizing rhombohedral $\mathrm{Bi}_{2} \mathrm{O}_{3}$ conductivity for low temperature SOFC electrolytes. Ionics 2019. [CrossRef]

23. Wang, J.; Chen, X.; Xie, S.; Chen, L.; Wang, Y.; Meng, J.; Zhou, D. Bismuth tungstate/neodymium-doped ceria composite electrolyte for intermediate-temperature solid oxide fuel cell: Sintering aid and composite effect. J. Power Sources 2019, 428, 105-114. [CrossRef]

24. Jung, D.W.; Duncan, K.L.; Wachsman, E.D. Effect of total dopant concentration and dopant ratio on conductivity of $\left(\mathrm{DyO}_{1.5}\right)_{x}-\left(\mathrm{WO}_{3}\right)_{y}-\left(\mathrm{BiO}_{1.5}\right)_{1-x-y}$. Acta Mater. 2010, 58, 355-363. [CrossRef]

25. Li, G.; Li, L.; Feng, S.; Wang, M.; Zhang, L.; Yao, X. An Effective Synthetic Route for a Novel Electrolyte: Nanocrystalline Solid Solutions of $\left(\mathrm{CeO}_{2}\right)_{1-x}\left(\mathrm{BiO}_{1.5}\right)_{x}$. Adv. Mater. 1999, 11, 146-149. [CrossRef]

26. Chen, X.L.; Eysel, W. The Stabilization of $\beta-\mathrm{Bi}_{2} \mathrm{O}_{3}$ by $\mathrm{CeO}_{2}$. J. Solid State Chem. 1996, 127, 128-130. [CrossRef]

27. Bourja, L.; Bakiz, B.; Benlhachemi, A.; Ezahri, M.; Valmalette, J.C.; Villain, S.; Gavarri, J.R. Structural and Raman Vibrational Studies of $\mathrm{CeO}_{2}-\mathrm{Bi}_{2} \mathrm{O}_{3}$ Oxide System. Adv. Mater. Sci. Eng. 2009, 2009, 1-4. [CrossRef]

28. Zagaynov, I.V.; Fedorov, S.V.; Konovalov, A.A.; Antonova, O.S. Perspective ceria-based solid solution of $\mathrm{Gd}_{x} \mathrm{Bi}_{0.2-x} \mathrm{Ce}_{0.8} \mathrm{O}_{2}$. Mater. Lett. 2017, 203, 9-12. [CrossRef]

29. Gil, V.; Tartaj, J.; Moure, C.; Duran, P. Effect of $\mathrm{Bi}_{2} \mathrm{O}_{3}$ addition on the sintering and microstructural development of gadolinia-doped ceria ceramics. J. Eur. Ceram. Soc. 2007, 27, 801-805. [CrossRef]

30. Li, Z.-C.; Zhang, H.; Bergman, B. Synthesis and characterization of nanostructured $\mathrm{Bi}_{2} \mathrm{O}_{3}$-doped cerium oxides fabricated by PVA polymerization process. Ceram. Int. 2008, 34, 1949-1953. [CrossRef]

31. Dikmen, S.; Shuk, P.; Greenblatt, M. Hydrothermal synthesis and properties of $\mathrm{Ce}_{1-x} \mathrm{Bi}_{x} \mathrm{O}_{2-\mathrm{d}}$ solid solutions. Solid State Ion. 1998, 11, 299-307. [CrossRef]

32. Prekajski, M.; Fruth, V.; Andronescu, C.; Trandafilović, L.V.; Pantić, J.; Kremenović, A.; Matović, B. Thermal stability of $\mathrm{Ce}_{1-x} \mathrm{Bi}_{x} \mathrm{O}_{2-\delta}(x=0.1-0.5)$ solid solution. J. Alloys Compd. 2013, 578, 26-31. [CrossRef]

33. Gil, V.; Tartaj, J.; Moure, C.; Duran, P. Rapid densification by using $\mathrm{Bi}_{2} \mathrm{O}_{3}$ as an aid for sintering of gadolinia-doped ceria ceramics. Ceram. Int. 2007, 33, 471-475. [CrossRef]

34. Accardo, G.; Kim, G.S.; Ham, H.C.; Yoon, S.P. Optimized lithium-doped ceramic electrolytes and their use in fabrication of an electrolyte-supported solid oxide fuel cell. Int. J. Hydrogen Energy 2019, 44, 12138-12150. [CrossRef]

35. Accardo, G.; Ferone, C.; Cioffi, R.; Frattini, D.; Spiridigliozzi, L.; Dell'Agli, G. Electrical and microstructural characterization of ceramic gadolinium-doped ceria electrolytes for ITSOFCs by sol-gel route. J. Appl. Biomater. Funct. Mater. 2016, 14, e35-e41. [CrossRef] [PubMed]

36. Lutterotti, L.; Bortolotti, M.; Ischia, G.; Lonardelli, I.; Wenk, H.-R. Rietveld texture analysis from diffraction images. Z. Kristallogr. Suppl. 2007, 2007, 125-130. [CrossRef]

(C) 2019 by the authors. Licensee MDPI, Basel, Switzerland. This article is an open access article distributed under the terms and conditions of the Creative Commons Attribution (CC BY) license (http://creativecommons.org/licenses/by/4.0/). 